Joanna Krajewska

ORCID: https://orcid.org/0000-0002-1449-8132

\title{
Dziedzictwo Docklands a transformacja dawnych terenów portowych Londynu. Obszar Bermondsey Riverside: od Tower Bridge do King's Stairs Gardens
}

\author{
The Docklands heritage and the transformation of the former \\ port areas of London. Bermondsey Riverside: from Tower \\ Bridge to King's Stairs Gardens
}

\begin{abstract}
After the rise of the British Empire, London docks have become the center of the world's commerce. Their unparalleled heritage is the result of their cultural and spatial uniqueness. Following their fall into disrepair in the second half of the $20^{\text {th }}$ century, a revitalization project was undertaken in the area under the blanket name of Docklands. In the 1980s, financial prosperity and the resulting boom in the construction industry enabled an accelerated transformation resulting in the gentrification of the district. The article aims at presenting the issues regarding marketization of the Docklands urban renewal processes in the context of its material and immaterial heritage. The author attempts at a cross-sectional view on the transformation taking a selected fragment of the Docklands, i.e. Bermondsey Riverside, focusing on the architectural changes. The author visited the area taken under scrutiny several times during the years 2008-2018.
\end{abstract}

Key words: heritage, former port areas, urban regeneration, Docklands, London

W okresie potęgi Imperium Brytyjskiego tereny portowe Londynu stanowiły centrum światowego handlu. Wyróżniała je szczególna odrębność przestrzenna i kulturowa, składające się na ich niepowtarzalne dziedzictwo. Gdy w 2. połowie XX wieku uległy degradacji, tereny te objęto programem rewitalizacji pod wspólną nazwą Docklands, by w latach 80. XX wieku - czasach finansowej prosperity i boomu budowlanego poddać je przyspieszonej transformacji architektoniczno-urbanistycznej. Konsekwencją wprowadzonych zmian była m.in. gentryfikacja. Celem artykułu jest przedstawienie problematyki urynkowienia procesu rewitalizacji dawnych terenów portowych wobec ich dziedzictwa materialnego i niematerialnego. Autorka 
podejmuje próbę przekrojowego spojrzenia na transformację wybranej części Docklands, z akcentem na przemiany, jakich dokonano na polu architektury. Analizowany obszar Bermondsey Riverside odwiedziła kilkakrotnie w latach 2008-2018.

Słowa kluczowe: dziedzictwo, dawne tereny portowe, rewitalizacja, Docklands, Londyn

Odebrano / Received: 31.01.2019

Zaakceptowano / Accepted: 27.08.2019

Przestrzeń Tamizy od London Bridge do Albert Docks tak się ma do innych nadrzecznych dzielnic portowych jak dziewiczy las do ogrodu. Tej dzielnicy nie zbudowano, wyrosta sama przez się. Przypomina dizungle niewyraźnym, różnorodnym i nieprzeniknionym wygladem budynków wzdtu̇ brzegu, nie rozmieszczonych wedtug celowego planu, lecz jakby wyrostych przypadkiem z rozsypanych nasion. Niby sktębiona masa zarośli i lian, przestaniająca ciche gtębie niezbadanej dziczy, kryją te zabudowania gtębiny londynskiego życia, nieskończenie różnorodnego i kipiacego sita. W innych nadrzecznych portach jest inaczej. Otwierają się ku swej rzece bulwarami (...). Lecz Londyn, najstarszy i największy z portów rzecznych, nie posiada nawet stu jardów otwartych bulwarów wzdtuz rzeki. Ciemne w nocy i nieprzeniknione jak oblicze lasu jest londynskie wybrzeże. Jest to

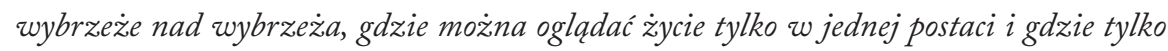
jeden rodzaj ludzi pracuje znojnie na skraju rzeki. Ciemne w nocy i nieprzeniknione jak oblicze lasu btota, na którym leża barki wyciagnięte na brzeg, a wąskie uliczki schodzace

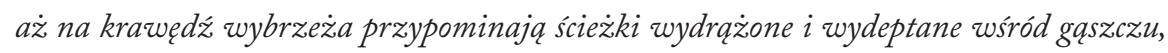
którymi gruba zwierzyna schodzi pić na brzegi podzwrotnikowych strumieni.

Joseph Conrad ${ }^{1}$

Z opisu londyńskich terenów portowych autorstwa Josepha Conrada, które widział jako marynarz $\mathrm{w}$ trzech ostatnich dekadach XIX wieku², wyłania się specyficzny, tajemniczy obraz przestrzeni ${ }^{3}$ i żyjących tam ludzi. Była to swoista strefa „pomiędzy

1 Conrad 1969, s. 128-129.

2 Książka Josepha Conrada Zwierciadto morza: opowieść została opublikowana w 1906 r. Autor opisuje $\mathrm{w}$ niej swoje wspomnienia z czasów, gdy pracował jako marynarz w latach 1874-1894. Warto nadmienić, że cała jego marynarska służba przypada na okres panowania królowej Wiktorii (1837-1901; od 1876 r. noszącej także tytuł cesarzowej Indii), powszechnie uważany za czasy świetności Imperium Brytyjskiego. Museum of London Docklands poświęca Conradowi fragment ekspozycji.

3 O londyńskim porcie, w podobnym duchu jak Conrad, pisał wcześniej John Ruskin w Modern Painters z 1843 r., odmalowując młodość Williama Turnera, który zapuszczał się w „ten tajemniczy las poniżej London Bridge - lepszy dla chłopca niż las sosnowy czy zagajnik mirtu”; zob. Ackroyd 2011, s. 566. 
światami” - centrum władzy Imperium Brytyjskiego a podległymi mu obszarami i zamorskimi ośrodkami handlu. Londyn, wówczas największa stolica na świecie i port do ładunków masowych, właśnie za sprawą terenów wzdłuż Tamizy wyróżniał się, według Conrada, „charakterem na wskroś odrębnym” wśród „arystokracji handlowych punktów ziemi" ${ }^{4}$. Specyfikę krajobrazu miejskiego dopełniał przywoływany w literaturze faktu, a także wielokrotnie utrwalany przez malarzy i grafików widok "gęstej siatki żagli i masztów" ${ }^{\prime \prime}$. Ludzie pracujący w tej strefie, m.in. przy jednostkach pływających i rozładunku, policjanci ${ }^{6}$, a ponadto osoby z tzw. półświatka, tworzyli odrębną społeczność 7 , która miała własny slang. Tereny doków zamieszkiwało ponadto bardzo wiele mniejszości etnicznych ${ }^{8}$; tu też dopuszczalna była większa swoboda wyrażania myśli niż w innych dzielnicach Londynu'.

Do 1880 roku londyńskie doki stały się centrum światowego handlu. Przed wybuchem II wojny światowej ciągnące się wzdłuż rzeki magazyny mieściły „każdy możliwy do wyobrażenia towar"10. Skalę zjawiska obrazują informacje, że w latach 30. XX w. w porcie i dokach Londynu pracowało 100 tysięcy ludzi, przechodziło przez nie 35 milionów ton towarów rocznie, zaś nabrzeży przeładunkowych było niemal 2 tysiące ${ }^{11}$. Można powiedzieć, że był to znak potęgi Imperium Brytyjskiego, dający wyobrażenie o jego terytorium (zasięgu) i bogactwie. Fakt ten oraz podkreślana przez obserwatorów unikatowość strefy portowej w wymiarze przestrzennym, krajobrazowym oraz społecznym, składają się na rangę dziedzictwa - materialnego i niematerialnego - jaka zdaje się przypadać w udziale tym terenom.

W wyniku nalotów bombowych podczas II wojny światowej zrujnowane zostały znaczne obszary portowe. Choć po wojnie dokonano odbudowy i port funkcjonował nadal, to od lat 60 . XX wieku tereny te zaczęły podlegać degradacji. Przyczyną było przejście na logistykę kontenerową, a także budowa statków zbyt dużych (tankowce,

\footnotetext{
Świadectw fascynacji londyńskimi dokami z czasów ich budowy i świetności, jakich doświadczali artyści i inni obserwatorzy, znajdziemy w literaturze więcej; zob. Ackroyd 2011.

${ }^{4}$ Conrad 1969, s. 133-134.

${ }^{5}$ Ackroyd 2011, s. 568; por. Conrad 1969.

${ }^{6}$ Policja Tamizy (ang. the Thames River Police) to najstarsze nieprzerwanie działające siły policyjne na świecie; Museum of London Docklands, 8.01.2018.

${ }^{7}$ Conrad 1969, Ackroyd 2011. Obszernym źródłem informacji dotyczących dawnych terenów portowych Londynu jest ekspozycja w Museum of London Docklands zlokalizowanym na terenie Canary Wharf.

${ }^{8}$ W źródłach Museum of London Docklands wymienieni zostali: Irlandczycy, Żydzi, Skandynawowie, Chińczycy, Afrykanie, byli niewolnicy z Karaibów i inni; ponadto doki odwiedzali marynarze z całego świata.

${ }^{9}$ Ackroyd 2011.

${ }^{10}$ Museum of London Docklands, 8.01.2018; Peter Ackroyd jako towary importowane wymienia: „herbatę, porcelanę, bawełnę i pieprz z Azji Południowo-Wschodniej, rum, kawę, cukier i kakao z Indii Zachodnich, tytoń, kukurydzę, ryż i olej z Ameryki, a także konopie, łój, żelazo i len z państw nadbałtyckich”; Ackroyd 2011, s. 565.

${ }^{11}$ Ackroyd 2011, s. 569- 570.
} 
kontenerowce) jak na londyńskie doki ${ }^{12}$. Zamknięto wówczas także zlokalizowane na wybrzeżach Tamizy zakłady przemysłowe, skutkiem czego do połowy lat 70. ponad 150 tysięcy ludzi straciło pracę ${ }^{13}$. Doki opustoszały. Rząd i lokalne władze podjęły wtedy próbę ich „dźwignięcia”, powołując organizacje mające opracować strategie rewitalizacji, m.in. Docklands Joint Committee ${ }^{14}$ oraz Docklands Development Organisation. Wówczas to wszystkie byłe tereny portowe (Bermondsey Riverside, Surrey Docks, Wapping, Limehouse, Isle of Dogs, Royal Docks oraz Beckton) objęto wspólną nazwą Docklands ${ }^{15}$. Jednak $\mathrm{z}$ intensywnymi pracami budowlanymi trzeba było poczekać na odpowiednią koniunkturę.

Rewitalizacja Docklands rozpoczęła się w latach osiemdziesiątych XX wieku, $\mathrm{w}$ czasie finansowej prosperity, skutkującej m.in. boomem budowlanym. Miało to związek z liberalną polityką gospodarczą Margaret Thatcher (sprawującej urząd premiera Wielkiej Brytanii w latach 1979-1990). Deregulacje pozwoliły inwestorom na śmiałe posunięcia biznesowe, wsparte specjalną polityką gospodarczą dotyczącą obszarów Docklands. W architekturze był to okres rozwoju postmodernizmu ${ }^{16}$, szybkiej kariery nurtu high-tech ${ }^{17}$ oraz dostrzeżenia wartości estetycznych stylu industrialnego ${ }^{18}$. Dawne tereny portowe stanowiły zatem atrakcyjne pole działania także dla architektów, pozwalając na interwencje w zastaną tkankę miejską zgodnie $\mathrm{z}$ aktualnymi trendami projektowymi. W 1981 roku rząd powołał organizację The London Docklands Development Corporation (LDDC), której celem miało być szybkie i efektywne zarządzanie urbanistyczną rewitalizacją byłych terenów portowych. Do jej zadań należały uzbrojenie terenu i budowa odpowiedniej infrastruktury (aby ziemie nadawały się do szybkiej sprzedaży pod inwestycje) oraz zmiana wizerunku East End - wschodniej części Londynu, przez ukształtowanie tożsamości miejsca w oparciu o historyczną przeszłość, architektoniczne znaczenie i położenie Docklands. Finansowanie organizacji pochodziło z rządowych

${ }^{12} \mathrm{Z}$ prezentacji pt. "The Changing Fortunes of London's Docklands" wygłoszonej podczas konferencji "Regeneration and Renewal Conference" w Birmingham, dn. 1.04.2009, Prezentacja konferencyjna Stewarta Innesa, 24.01.2018.

${ }^{13}$ Prezentacja konferencyjna Stewarta Innesa, 24.01.2018.

${ }^{14}$ Komitet m.in. wydał w 1976 r. publikację dotyczącą strategii odbudowy tych terenów: "London docklands: A strategic plan: a draft ... for public consultation”; Docklands Joint Committee 1976.

15 Prezentacja Stewarta Innesa, 24.01.2018.

${ }^{16}$ Określenie dotyczy ogółu prądów w architekturze XX i XXI w.; spopularyzowane w 1978 r. za sprawą publikacji w The New York Times prezentującej projekt biurowca AT\&T Building autorstwa Philipa Johnsona; często dotyczy architektury o charakterze eklektycznym; Jencks 1987.

${ }^{17}$ High-tech oznacza zaawansowaną technologię (ang. high technology); nurt ten bywa zaliczany do szeroko rozumianego postmodernizmu. Czołowym przykładem architektury high-tech jest ukończony w $1986 \mathrm{r}$. biurowiec firmy ubezpieczeniowej Lloyd's, zrealizowany według projektu brytyjskiej firmy architektonicznej Richard Rogers and Partners w dzielnicy finansowej City of London. Styl high-tech wyróżnia się eksponowaniem instalacji i funkcji pomocniczych na zewnątrz budynku (tzw. metoda "inside-out"), co niezależnie od przeznaczenia, nadaje mu przemysłowy charakter.

${ }^{18}$ Jencks 1987. 
dotacji oraz dochodów ze sprzedaży gruntów ${ }^{19}$. Jej działanie miało objąć okręgi Tower Hamlets, Newham i Southwark (w obrębie którego znajduje się Bermondsey) ${ }^{20}$. Studium LDDC wykonane w 1981 roku wykazało zły stan terenów należących niegdyś do strefy portowej. W owym czasie 95\% zabudowy stanowiły budynki socjalne ${ }^{21}$, część obszarów była porzucona i niezagospodarowana. By wspomóc akcję odbudowy, stworzono kilka specjalnych stref gospodarczych (wprowadzono np. ulgi podatkowe) oraz sieć transportową ${ }^{22}$. Rewitalizacja Docklands nabrała tempa i rozwijała się w chaotyczny, można rzec „spontaniczny” sposób (strategią działania LDDC było m.in. unikanie tworzenia Masterplanów, co wydłużyłoby cały proces inwestycyjny ${ }^{23}$ ). W pierwszych dziesięciu latach organizacja wydała około miliarda funtów brytyjskich na infrastrukturę i zagospodarowanie, przyciągając dzięki temu prywatnych inwestorów (inwestycje na kwotę 10 miliardów funtów) ${ }^{24}$. Efektem tych działań było między innymi wybudowanie do 1998 roku na terenie Docklands ponad 24 tysięcy mieszkań oraz stworzenie 85 tys. miejsc pracy ${ }^{25}$, jednak niosło to ze sobą także „uboczne” zjawiska społeczno-przestrzenne - takie jak gentryfikacja ${ }^{26}$, funkcjonalne ujednolicenie dużych obszarów przywróconych miastu (enklawy mieszkalne), czy brak spójności kompozycyjnej dawnego obszaru portowego ${ }^{27}$. W tym czasie zaczęto się również posługiwać określeniem „dziedzictwo” w odniesieniu do obszarów Docklands, co prawdopodobnie miało legitymizować prowadzone wówczas przyspieszone działania rewitalizacyjne ${ }^{28}$. Termin pomagał skierować uwagę opinii publicznej na obiekty portowe i infrastrukturę (dawne magazyny i baseny)

${ }^{19}$ Beswick 2001.

${ }^{20}$ Beswick 2001; por. Prezentacja Stewarta Innesa, 24.01.2018.

${ }^{21}$ Prezentacja Stewarta Innesa, 24.01.2018, Załuski 1998, s. 16.

${ }^{22}$ Ackroyd 2011, s. 759; por. Załuski 1998, Lorens 2013.

${ }^{23}$ Beswick 2001.

${ }^{24}$ Edwards 1992, s. XI.

${ }^{25}$ Szczegółowe informacje nt. działalności LDDC znajdują się na stronie: LDDC, 6.02.2018; por. Edwards 1992, Załuski 1998.

${ }^{26}$ Eukasz Drozda w swojej pracy na temat gentryfikacji jako autorkę pojęcia podaje brytyjską socjolożkę Ruth Glass, która w latach 60. XX w. zaobserwowała proces wypierania dotychczasowych mieszkańców z niektórych dzielnic Londynu. W jej ujęciu gentryfikacja (od ang. gentry - szlachta) oznacza „uszlachetnianie", ale z wydźwiękiem ironicznym; Drozda 2017, s. 40-41. O zjawisku gentryfikacji na terenach Docklands pisze m.in. Tim Butler w artykule Re-urbanizing London Docklands: Gentrification, Suburbanization or New Urbanism?; zob. Butler 2007. Piotr Lorens wskazuje na znaczący wzrost liczby osób bezdomnych oraz oczekujących na przydział mieszkania socjalnego, co jest związane z przeobrażeniami na terenach Docklands, zob. Lorens 2013, s. 36.

${ }^{27}$ Lorens 2013, s. 36.

${ }^{28}$ Przykładem mogą być publikacje z lat 80. XX w., jak ta z 1987 r. zatytułowana Docklands Heritage: Conservation and Regeneration in London Docklands wydana przez LDDC pod redakcją Carole Lyders i Averil Harrison. Co ciekawe, na stronie internetowej poświęconej angielskiemu dziedzictwu (ang. heritage) nie znajduje się żadna informacja dot. Docklands; zob. English Heritage, 6.02.2018. 
warte zachowania i ochrony ${ }^{29}$, jako elementy miejskiego pejzażu; ułatwiał jednocześnie dokonywanie działań na tkance miejskiej, przy udziale odpowiednich środków finansowych, by przygotować pole dla przyszłych inwestycji ${ }^{30}$.

Nie sposób w zwięzłym opracowaniu ująć wszystkich przemian, jakie miały miejsce na całym obszarze Docklands od początku ich rewitalizacji. Do analizy zdecydowałam się wybrać teren, który staram się zawsze odwiedzać podczas moich pobytów w Londynie, czyli Bermondsay Riverside na odcinku Tower Bridge - King's Stairs Gardens. $Z$ tego obszaru wyłączyłam rejon położony między mostami London Bridge i Tower Bridge (mieszczący m.in. londyński ratusz i szklany kompleks biurowy - oba projekty pracowni Foster and Partners zrealizowane w XXI w.), z uwagi na jego odrębność funkcjonalną (usługi i administracja publiczna) i stylistyczną (zróżnicowanie stylów architektonicznych) w stosunku do terenów położonych poniżej Tower Bridge.

Podczas spacerów wśród dawnych magazynów zamienionych na komfortowe mieszkania z kameralnymi lokalami gastronomicznymi w przyziemiu, dużą przyjemność sprawia odkrywanie śladów przeszłości i coś, co można nazwać obcowaniem z historią. O mieście jako „potężnym kondensatorze pamięci, kumulującym doświadczenia kolejnych generacji” pisze Bogusław Żyłko, odwołując się do prac Jurija Łotmana i innych badaczy ze szkoły tartusko-moskiewskiej. Wskazuje przy tym na zasadność spotykanej obecnie $\mathrm{w}$ literaturze przedmiotu metafory miasta-palimpsestu ${ }^{31}$, wobec wielowarstwowości tekstu kultury, jakim jest miasto ${ }^{32}$. I to współistnienie przeszłości i współczesności, nałożonych na siebie w tkance miejskiej, tak widoczne w wielu dzielnicach Londynu - jest obecne także w Bermondsey. Widok łodzi zacumowanych wzdłuż wybrzeża oraz barek mieszkalnych tuż przy błotnistym brzegu Tamizy wprowadza przechodnia w atmosferę portową, podobnie jak dawny dok (St. Saviour's Dock) wcinający się w ląd aż do ulicy Jamaica Rd. Jednak przestrzeń za pierwszą linią zabudowy wydaje się być zbyt spokojna i „czysta” (wyczyszczona?), jak na swoją szczególną przeszłość33. Można odnieść wrażenie, że miasto (reprezentowane w tym przypadku przede wszystkim przez klasę średnią) zaanektowało na swoje potrzeby ten obszar, tak niegdyś odręb-

${ }^{29} \mathrm{~W}$ tym rozumieniu „dziedzictwo" jest traktowane w kategoriach materialnych jako przedmiot konserwacji i zarządzania przez odpowiednie instytucje, pozwalający przywołać przeszłość, także jako obiekt turystyczny; zob. Macdonald 2013.

${ }^{30} \mathrm{Na}$ problem komercjalizacji dziedzictwa zwraca uwagę między innymi Sharon Macdonald, zob. Macdonald 2013.

${ }^{31}$ Zob. Ewa Rewers: miasto postindustrialne; Rewers 2005.

32 Żyłko 2011, s. 126.

33 Przywołaną „czystość” rozumie się tu zarówno dosłownie, jak i metaforycznie, w odniesieniu do zniszczeń wojennych oraz działań w ramach programu rewitalizacji, który przygotował ten obszar pod nowe inwestycje. Likwidacja („wyczyszczenie”) niektórych śladów przeszłości zmieniła część terenów Docklands w rodzaj „białej karty”, na której można było tworzyć miejskość od nowa. Odwiedzając opisywaną okolicę, ma się wrażenie, że usunięto z niej wszystko to, co brzydkie i prowizoryczne; jednocześnie wydaje się, że brak w niej życia. 
ny od pozostałych dzielnic Londynu. Ciche, puste za dnia ${ }^{34}$, monitorowane uliczki, niczym nie przypominają swą atmosferą tych opisywanych przez Josepha Conrada. Bermondsey Riverside zamieniła się w zwykłą dzielnicę mieszkalną - nieco bardziej gwarną w bezpośrednim sąsiedztwie Tower Bridge i zupełnie spokojną, niemal o charakterze przedmieścia, we wschodniej części sąsiadującej z parkiem King's Stairs Gardens. Kontynuacja funkcji doków w formie, w jakiej działały one na przełomie XIX i XX wieku jest niemożliwa (w części, np. St. Katharine Docks, cumują obecnie jachty). Próby celowej rekonstrukcji tej przestrzeni w aspekcie historyczno-społecznym skazane byłyby zapewne na niepowodzenie. Można jednak postawić pytanie, czy potencjał tego dawnego obszaru portowego - z uwagi na dziedzictwo Docklands - został w pełni wykorzystany. Co zostało z plątaniny ulic, monumentalnych ceglanych ścian kształtujących architekturę portową oraz z lokalnej kultury?

Tematyce rewitalizacji Docklands w ujęciu architektoniczno-urbanistycznym poświęcono wiele publikacji książkowych $\mathrm{i}$ innych opracowań. $Z$ obszernej literatury warto przytoczyć książkę London Docklands: Urban Design in an Age of Deregulation ${ }^{35}$ Briana Edwardsa, który wielokrotnie rozmawiał z architektami biorącymi udział w opisywanym przedsięwzięciu, a także pracę City Reborn: Architecture and Regeneration in London, from Bankside to Dulwich autorstwa krytyka architektury Kennetha Powella ${ }^{36}$, analizującego południowy obszar miasta, w tym interesujący mnie rejon Bermondsey. Również polscy badacze podejmowali problematykę przemian dawnych dzielnic portowych, także na obszarze Londynu. Wymienić można zwłaszcza pracę zbiorową pod redakcją Mieczysława Kochanowskiego Wspótczesne metamorfozy miast portowych" ${ }^{37}$ oraz publikację Piotra Lorensa Obszary poportowe - problemy rewitalizacji ${ }^{38}$, których autorzy dokonali przeglądu i ogólnej charakterystyki programów rewitalizacji. $Z$ uwagi na przytoczone opracowania, wymienię jedynie kilka kluczowych realizacji, jako przykłady podejścia projektantów do architektonicznego dziedzictwa Docklands.

Od lat 80. XX wieku na opisywanym terenie Bermondsey wybudowano szereg zespołów mieszkaniowych oraz dokonano rewitalizacji zabudowy portowej, wprowadzając funkcję mieszkalną w miejsce magazynowej. Do najbardziej charakterystycznych

\footnotetext{
${ }^{34}$ Aby uzyskać pełny obraz całodobowego życia toczącego się na tym terenie, konieczne byłoby prowadzenie obserwacji uczestniczącej, przez dłuższy czas, w różnych sezonach (np. wakacyjnym, zimowym).

35 Edwards 1992.

${ }^{36}$ Powell 2004.

${ }^{37}$ Rewitalizacja obszaru Docklands w ujęciu całościowym, w kontekście działań LDDC oraz pozytywne przykłady zrewitalizowanych obiektów na czterech obszarach zarządzania rozwojem, zob. Załuski 1998; ogólna charakterystyka zmian przestrzeni poportowych w kierunku rozwoju przestrzeni publicznych, zob. Kochanowska 1998; analiza porównawcza brytyjskich i amerykańskich programów rewitalizacyjnych, zob. Lorens 1998.

${ }^{38}$ Autor przedstawia ogólną charakterystykę działań rewitalizacyjnych na terenie Docklands oraz związane z tymi działaniami problemy organizacyjne; dokonuje analizy porównawczej procesów i programów z działaniami na terenie innych obszarów poportowych w Europie i Ameryce Północnej; Lorens 2013.
} 
inwestycji z tego okresu należą rewitalizacje Butler's Wharf (Masterplan 1983), China Wharf (1988) i budowa kompleksu The Circle (1989). Wszystkie trzy projekty powstały w londyńskich biurach architektonicznych. Obejmujący kilka kwartałów, wielofunkcyjny zespół zabudowy (lofty, powierzchnie biurowe i niewielkie lokale usługowe, jak również Muzeum Designu w stylu modernistycznym), którego flagowym obiektem jest Butler's Wharf ${ }^{39}$, zaprojektowała na nowo firma Conran + Partners ${ }^{40}$. Dyrektor Muzeum Designu, Deyan Sudijc, opisał zrewitalizowany obszar jako ,jedną z najatrakcyjniejszych dzielnic (ang. neighbourhoods) Londynu"41. Częściowo przebudowana, częściowo zaadaptowana architektura portowa zachowała industrialny charakter dzięki połączeniu cegły i elementów stalowych, a także pozostawieniu historycznych detali i urządzeń inżynierskich. Szczególne wrażenie doświadczania przeszłości można mieć podczas spaceru uliczką Shad Thames ${ }^{42}$ wzdłuż Butler's Wharf - niegdyś największego magazynu herbaty na świecie. Pomiędzy nim a The Cardamon Building (dawnym magazynem przypraw $)^{43}$ przerzucone zostały pomosty, pełniące obecnie funkcję prywatnych tarasów (fot. 1). Oba budynki znajdują się w rejestrze brytyjskiej architektury o szczególnym znaczeniu (historycznym bądź architektonicznym), tzw. British Listed Buildings (w kategorii II), co chroni je przed istotną przebudową ${ }^{44}$ (główną widoczną zmianą są powstałe nadbudowy, wykonane jednak $\mathrm{z}$ dużym poszanowaniem zastanej struktury). Jako dawny kompleks magazynowy formują największą zachowaną w Londynie grupę budowli z czasów wiktoriańskich ${ }^{45}$. Rewitalizacja China Wharf, podobnie jak The Circle, powstała pod kierunkiem zespołu CZWG Architects ${ }^{46}$. Znany krytyk architektury Charles Jencks określił projekt China Wharf jako „kanon” rewitalizacji terenów portowych ${ }^{47}$. Uwage przyciąga nadbrzeżna elewacja apartamentowca, którą jeden z szefów biura CZWG Architects, Piers Gough, opisuje słowami: „po części łódź, po części pagoda, i bardzo czerwona" ${ }^{48}$, wskazując jednocześnie na historyczne i kulturowe inspiracje dla tego projektu ${ }^{49}$ (fot. 2). Wybijająca się na tle przeszkleń, jaskrawo pomalowana, sy-

${ }^{39}$ Jak podaje Carol-Ann Beswick za Royal Docks Trust, swoją nazwę budynek zawdzięcza panu Butlerowi, który wynajął magazyn w 1794 r., by przechowywać w nim zboże; Beswick 2001.

${ }^{40}$ Siedziba biura mieści się na tym terenie, przy dawnym akwenie portowym (przy Shad Thames); Conran + Partners, 26.01.2018.

${ }^{41}$ Conran + Partners, 26.01.2018.

${ }^{42} \mathrm{~W}$ pracach badawczych rewitalizacja zabudowy przy Shad Thames jest szczególnie pozytywnie oceniana, zob. Edwards 1992, s. 91, Załuski 1998, s. 18-19.

${ }^{43}$ The Cardamon Building, 6.02.2018.

${ }^{44}$ British Listed Buildings, 6.02.2018.

${ }^{45}$ Beswick 2001.

${ }^{46}$ CZWG, 20.01.2018.

${ }^{47}$ Powell 2004, s. 21.

${ }^{48}$ Powell 2004, s. 36; ttum. J.K.

${ }^{49}$ China Wharf było miejscem rozładunku towarów z Chin, stąd nawiązanie do tradycyjnej chińskiej architektury - pagody oraz użycie koloru czerwonego (w Chinach szczególnie nacechowanego symbolicznie). 
metryczna część centralna, z trzema rzędami balkonów i półkolistymi otworami na osi, wsparta na masywnych betonowych filarach, zawiera odwołania zarówno do chińskiej kultury, jak i architektury portowej. Najniższy balkon, znajdujący się między środkowymi filarami, utworzono $z$ fragmentu łodzi, jak gdyby ta wypływała spomiędzy nich. Poniżej widać mulisty brzeg, a zacumowane nieopodal barki mieszkalne i łodzie, do których prowadzą lekkie pomosty, przypominają o dawnym charakterze tej okolicy. Pobliski St. Saviour's Dock, wzdłuż którego ponad rzędami drewnianych pali i betonowych umocnień wyrastają ceglane ściany zabudowy (obecnie głównie mieszkaniowej) z rzędem żurawi portowych, także zaświadcza o przeszłości miejsca. Położony nieopodal kompleks mieszkalny The Circle tworzy ceglana, kilkukondygnacyjna zabudowa zwieńczona fantazyjną falą. Indywidualnego charakteru nadaje jej centralny plac o wymiarach gazometru $^{50}$, przy którym elewacje budynków wykończono niebieską glazurowaną cegłą (fot. 3). Projektanci opisują to miejsce jako „okrągły pokład kobaltu w kanionach londyńskiej surowej cegły" ${ }^{1}$. Reminiscencją przeszłości mają też być masywne podpory licznych balkonów, które przydają architekturze mieszkalnej wyglądu industrialnego.

Dawny browar Anchor Brewhouse ${ }^{52}$, tworzący nadbrzeżną pierzeję z Butler's Wharf (fot. 4), przebudowano w 1989 roku. Obecnie znajdują się w nim 62 mieszkania różnego typu (m.in. 3-piętrowy penthouse) ${ }^{53}$. Nad projektem pracowało londyńskie biuro Thomas Pollard Edwards (które opracowało także rewitalizację zabudowy New Concordia Wharf, sąsiadującego z China Wharf). Browar, stojący w pobliżu Tower Bridge, składał się z trzech połączonych budynków: kotłowni, warzelni i słodowni, tworzących malowniczy przykład wiktoriańskiej architektury przemysłowej. Architekci, podejmując się rewaloryzacji obiektu, starali się nadać mu możliwie oryginalny charakter (część centralna browaru została zbombardowana podczas II wojny światowej), z zachowaniem historycznych detali54. Obecnie znajduje się on w rejestrze British Listed Buildings (kat. II). W latach 1985 i 1987 rewaloryzacja Anchor Brewhouse została wyróżniona nagrodą konserwatorską Europa Nostra Conservation Award55. Wszystkie z opisanych zespołów zabudowy zawierają komfortowe mieszkania różnego typu (lofty,

\footnotetext{
${ }^{50}$ Pozwala to przypuszczać, że przed rewitalizacją dzielnicy był tu zlokalizowany gazometr.

${ }^{51}$ CZWG, 20.01.2018; tłum. J.K.

${ }^{52}$ Pierwszy browar funkcjonował w tym miejscu jeszcze przed 1787 rokiem, kiedy to niewielki wówczas budynek zakupił John Courage. Browarnictwo w tej okolicy jest wspomniane w utworze Horselydown Szekspira; informacje na temat browaru można znaleźć na stronie internetowej poświęconej dokumentacji miejsc pamięci w Londynie - zob. Anchor Brewhouse, 7.02.2018; informacje te znajdują się również na tablicy umieszczonej na elewacji budynku.

${ }^{53}$ Pollard Thomas Edwards, 6.02.2018.

${ }^{54}$ Pollard Thomas Edwards, 6.02.2018.

55 Pollard Thomas Edwards, 6.02.2018. Od 2002 roku podobna nagroda, przyznawana w ramach Unii Europejskiej, jest wręczana pod nazwą EU Prize for Cultural Heritage / Europa Nostra Awards, European Heritage Awards, 7.02.2018.
} 
studia itp.), które są oferowane pod wynajem na licznych stronach internetowych londyńskich agencji nieruchomości ${ }^{56}$.

$\mathrm{Na}$ obszarze Bermondsey Riverside przetrwało kilka lokalnych pubów - miejsc silnie związanych z tożsamością Londynu ${ }^{57}$. Jednym z nich jest Anchor Tap (fot. 5) przy Horselydown Lane, założony w 1761 roku (informacja ta znajduje się na tablicy umieszczonej na zewnątrz budynku; inne źródło podaje 1. połowę XIX wieku ${ }^{58}$ ), zlokalizowany w pobliżu Anchor Brewhouse. Historia tego miejsca jest spleciona $z$ historią piwa o nazwie Courage, wytwarzanego nieopodal od końca XVIII wieku w rodzinnym browarze o tej samej nazwie ${ }^{59}$. Puby to jedne $\mathrm{z}$ niewielu obiektów na tym obszarze, które zachowały swoją pierwotną funkcję. Przebywając w ich historycznych wnętrzach, można odnieść wrażenie doświadczania przeszłości (fot. 6). Widok drewnianej, dekorowanej lady ${ }^{60}$ oraz smukłych żeliwnych podpór, smak piwa z lokalnego browaru ${ }^{61}$, gwar rozmów, a nieraz bardzo specyficzny zapach - wszystko to wpływa na zmysły i wyobraźnię. Oprócz bogatej oferty napojów alkoholowych proponuje się tam m.in. grę w bilard lub rzutki. Można również obejrzeć transmisję popularnych w Anglii rozgrywek sportowych $^{62}$. To typowe miejsca spotkań londyńczyków, nadal pełniące istotną rolę kulturową $^{63}$. Niektóre lokale są nowo otwierane, jednak poprzez wystrój wnętrza i dbałość o atmosferę wpisują się w kontekst historyczny - przykładem może być Dean Swift zlokalizowany przy Gainsford Street, którego właściciele odwołują się do tradycji „domów piwnych" (ang. beer house) zakładanych w połowie XVIII wieku ${ }^{64}$. We wspomnianym pubie umieszczono m.in. tablicę informującą o pochodzeniu charakterystycznego smaku piwa IPA (India Pale Ale), związanego z eksportem jasnego piwa typu Ale do Indii w połowie XIX wieku, co stanowi nawiązanie do historii Docklands ${ }^{65}$.

${ }^{56}$ Zob. np. Urban Spaces, 25.01.2018.

57 Zob. Ackroyd 2011, s. 367-381.

${ }^{58}$ Pub Heritage, 30.06.2019.

${ }^{59}$ Piwo wytwarzane pierwotnie w browarze Johna Courage, połączonym następnie z browarem Anchor, do dziś jest sprzedawane pod tą samą nazwą; Courage\&Co., 30.06.2019.

${ }^{60}$ Szczegółowy opis wnętrza Anchor Tap znajduje się na stronie internetowej poświęconej „dziedzictwu pubów” - zob. Pub Heritage, 30.06.2019.

${ }^{61}$ Pub Anchor Tap, będąc obecnie własnością browaru Samuel Smith, w stałej ofercie ma obecnie piwo Samuel Smith Old Brewery Bitter. Tradycja tego najstarszego browaru z hrabstwa Yorkshire sięga połowy XVIII w.; informacje podaje przewodnik po pubach online - zob. CAMRA, 29.06.2019. Do Samuel Smith's należy także m.in. historyczny pub The Angel przy Bermondsey Wall E.

${ }^{62} \mathrm{~W}$ jednym $\mathrm{z}$ tamtejszych pubów oglądałam zawody jeździeckie na ekranie zamontowanym w głównej sali.

${ }^{63}$ Raport Instytutu Badań Polityki Społecznej (ang. Institute for Public Policy Research) z 2012 r. podaje, że „poza domem pub jest najbardziej popularnym miejscem dla Brytyjczyków w każdym wieku i z każdej klasy, by się zrelaksować i nawiązać stosunki towarzyskie"; Muir R. $2^{\text {nd }}$ (ed.) 2012, s. 4 (ttum. J.K).

${ }^{64}$ The Dean Swift, 29.06.2019.

${ }^{65}$ Doki, w których cumowały statki pływające do Indii (West India Dock oraz East India Dock), znajdowały się na obszarze Isle of Dogs (półwysep na wschód od Bermondsey). 
W przestrzeni publicznej Bermondsey spotyka się różnego typu formy upamiętniania przeszłości - także tej utrwalonej w zbiorowej pamięci dzięki fikcji literackiej. Semiotycy z grupy tartusko-moskiewskiej, analizując fenomen miasta, wiele uwagi poświęcili beletrystyce, wskazując na mitotwórczą rolę tekstów o mieście (tzw.x-tekstów) ${ }^{66}$. $\mathrm{Na}$ zbiorową wyobraźnię na temat dawnej przestrzeni Londynu wpłynęły zwłaszcza powieści Karola Dickensa (np. Barnaba Rudge, David Copperfield czy Oliver Twist) ${ }^{67}$. I tak oto badany fragment Bermondsey wiąże się z historią Olivera Twista, małego sieroty, który trafił do środowiska przestępczego. Specjalna strona internetowa pozwala odnaleźć miejsca, gdzie toczyła się akcja powieści - niektóre ulice istnieją do dziś i zachowały nazwy wymienione w utworze z 1838 roku (Dockhead i Mill St) ${ }^{68}$. Nie przetrwało jednak nic $z$ oddanej przez pisarza atmosfery tajemniczych i niebezpiecznych zaułków, które istniały tam w 1. poł. XVIII wieku, zamieszkiwane przez najbiedniejszą ludność Londynu (slumsy Jacob’s Island). O dawnym wyglądzie okolicy i jej związku $\mathrm{z}$ powieścią Dickensa przypomina przechodniom tablica umieszczona na jednym z budynków. Obecnie spokojna, w części elitarna dzielnica mieszkaniowa, tylko dzięki zachowanej zabudowie postindustrialnej i obiektom inżynierskim (dziedzictwo materialne) wyróżnia się wśród innych obszarów stolicy zamieszkiwanych przez klasę średnią.

Zwarta zabudowa Bermondsey Riverside na wschód od Mill Street ustępuje luźniejszej, a między budynkami pojawia się zieleń. Na tym obszarze szczególnie zwracają uwagę dwa nowe zespoły mieszkaniowe - kompleks trzech ceglanych budynków $\mathrm{z}$ zielonym dziedzińcem otwartym w kierunku Tamizy przy Bermondsey Wall $\mathrm{W}$ oraz położona nieco dalej, przy Chamber Street/East Lane, kameralna zabudowa z charakterystycznym podziałem elewacji. W pierwszym przypadku ciekawe jest rozwiązanie dziedzińca, gdzie urządzono ogród dostępny tylko dla mieszkańców (teren jest grodzony). Ponadto część zieleni znajduje się na wyspie, architektura zaś styka się bezpośrednio z wodą dzięki tarasom na parterze (fot. 7). Takie zagospodarowanie terenu, a także rozwiązania architektoniczne (cegła, masywne filary przechodzące przez dwie dolne kondygnacje) nawiązują do historycznej przeszłości tego miejsca ${ }^{69}$. Drugi z wymienionych zespołów mieszkalnych wyróżnia się zastosowaniem materiałów i tektoniką elewacji, dzięki którym możliwa jest subtelna gra z widzem w skojarzenia. Stalowe belki widoczne na elewacji, tworzące modułowe obramienia poszczególnych sekcji budynku, mogą przywodzić na myśl kontenery i funkcją magazynową. Podobnie oddziałują wypuszczane niekiedy z ceglanych elewacji drewniane wykusze. Dalej na wschód, w kierunku parku King's Stairs Gardens, okolica nabiera charakteru przedmieść ${ }^{70}$. Niską zabudowę

\footnotetext{
${ }^{66} \dot{Z}$ yłko 2011.

${ }^{67}$ Żyłko 2011, s. 127.

${ }^{68}$ Mapowanie Londynu wg powieści Karola Dickensa, 24.01.2018.

${ }^{69}$ Jednak fakt, że teren dziedzińca nie jest ogólnodostępny, zwiększa elitarność tego zespołu zabudowy.

${ }^{70}$ Można nawet zobaczyć niską zabudowę mieszkalną za drewnianymi ogrodzeniami.
} 


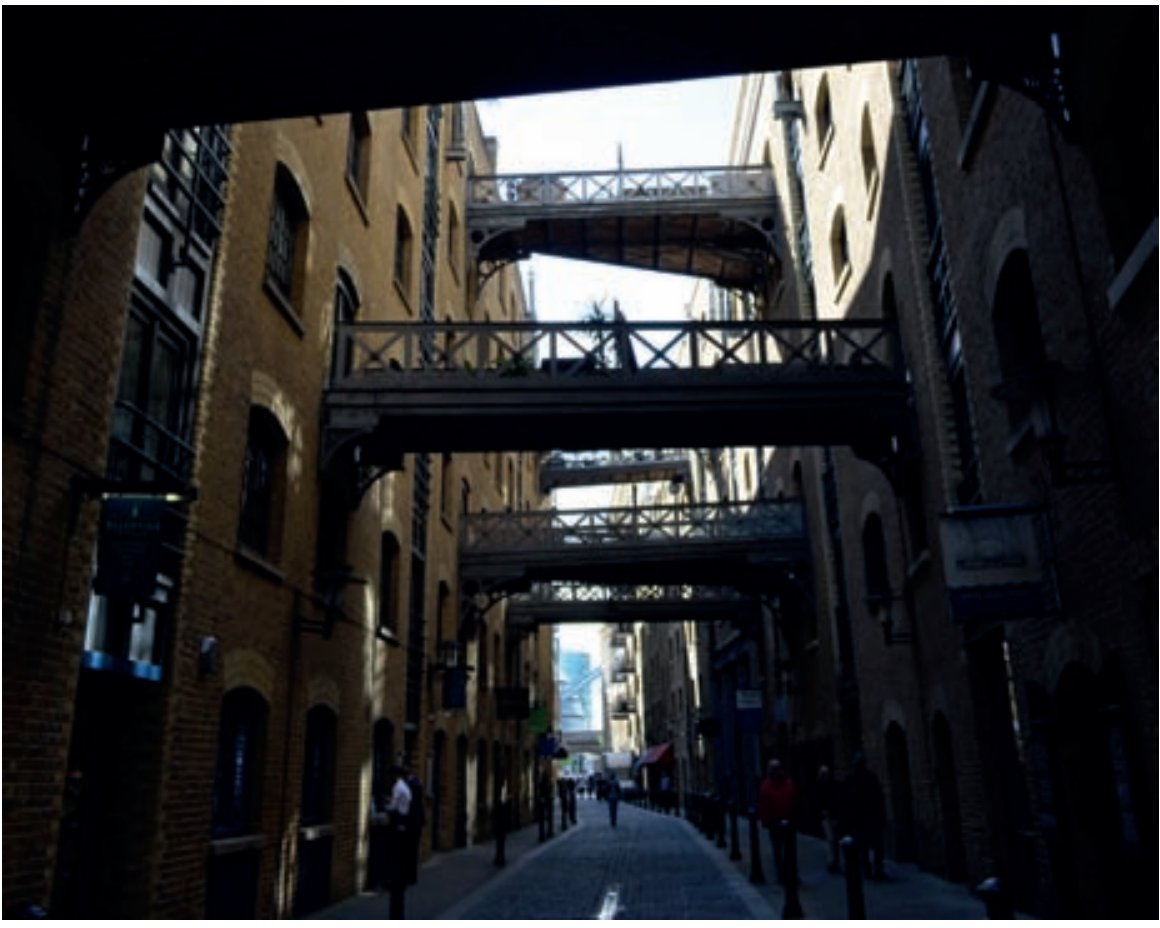

Fot. 1. Butler's Wharf - przerzucone pomosty pełnią obecnie funkcję tarasów, uliczka Shad Thames, Londyn, fot. J. Krajewska 2015

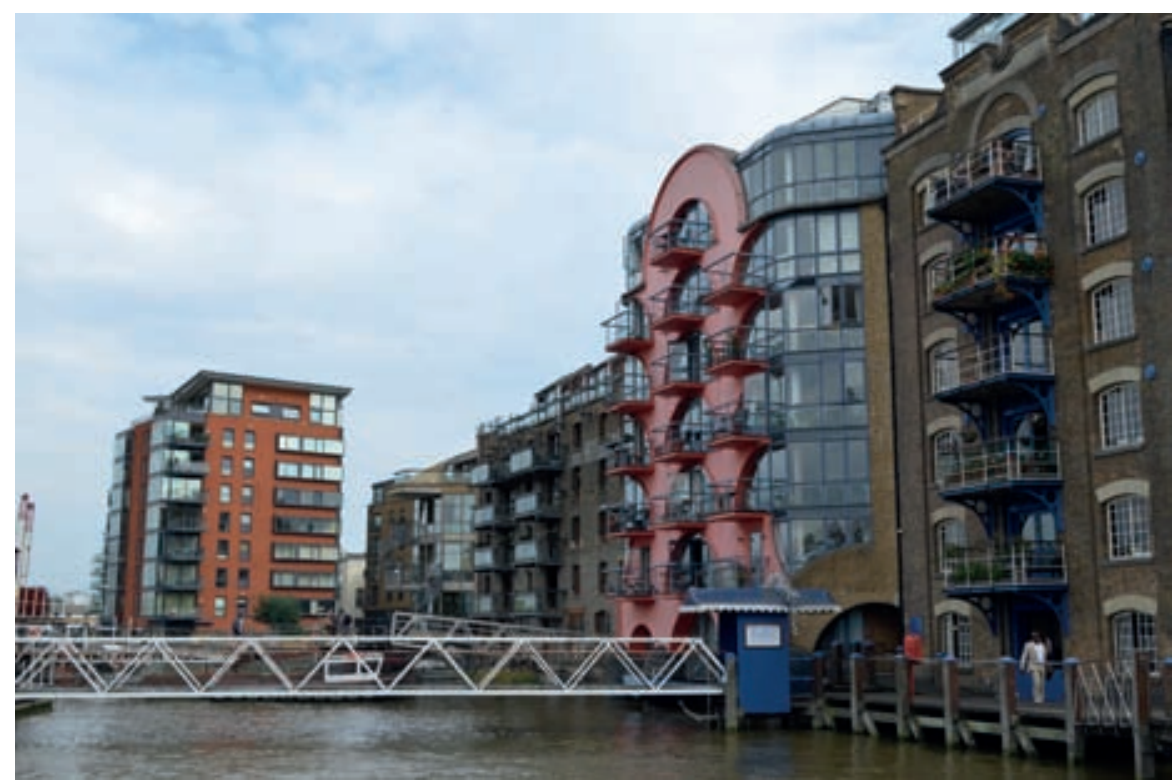

Fot. 2. China Wharf - czerwony budynek po prawej (proj. CZWG Architects 1988 r.), Londyn, fot. J. Krajewska 2018 


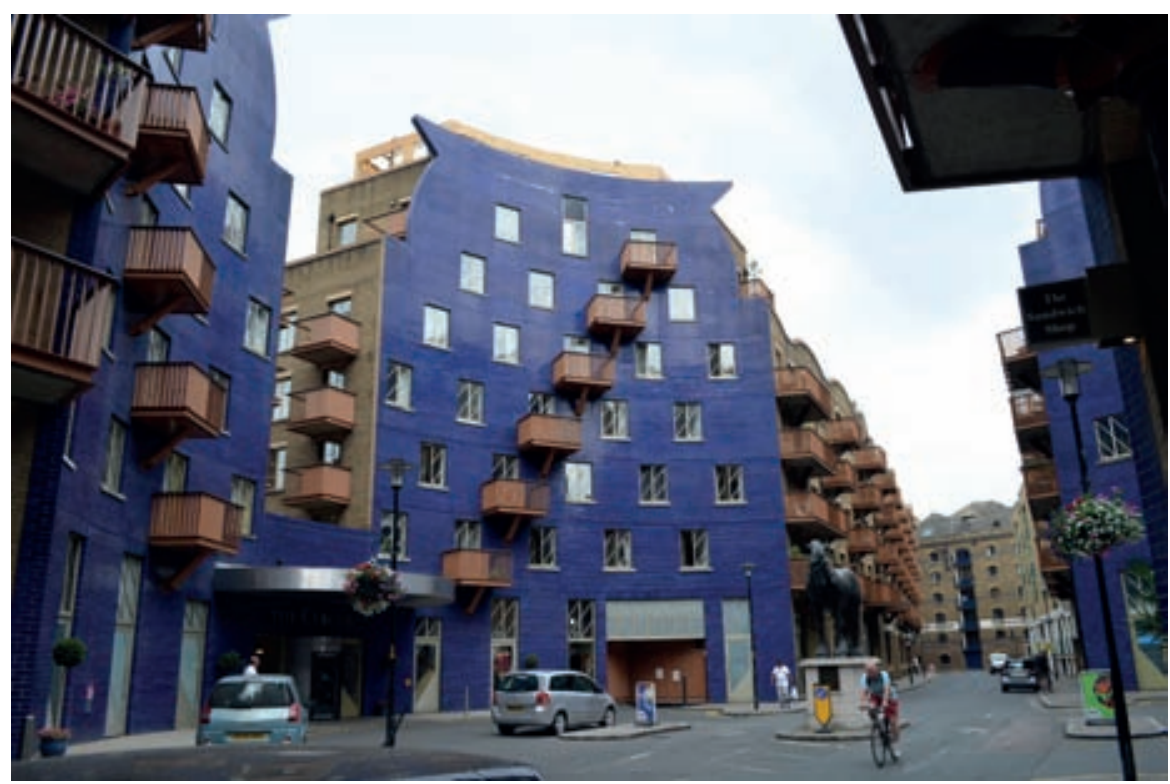

Fot. 3. Zabudowa mieszkaniowa The Circle (centralna część założenia) zlokalizowana w obrębie Bermondsey (proj. CZWG Architects 1989 r.), Londyn, fot. J. Krajewska 2018

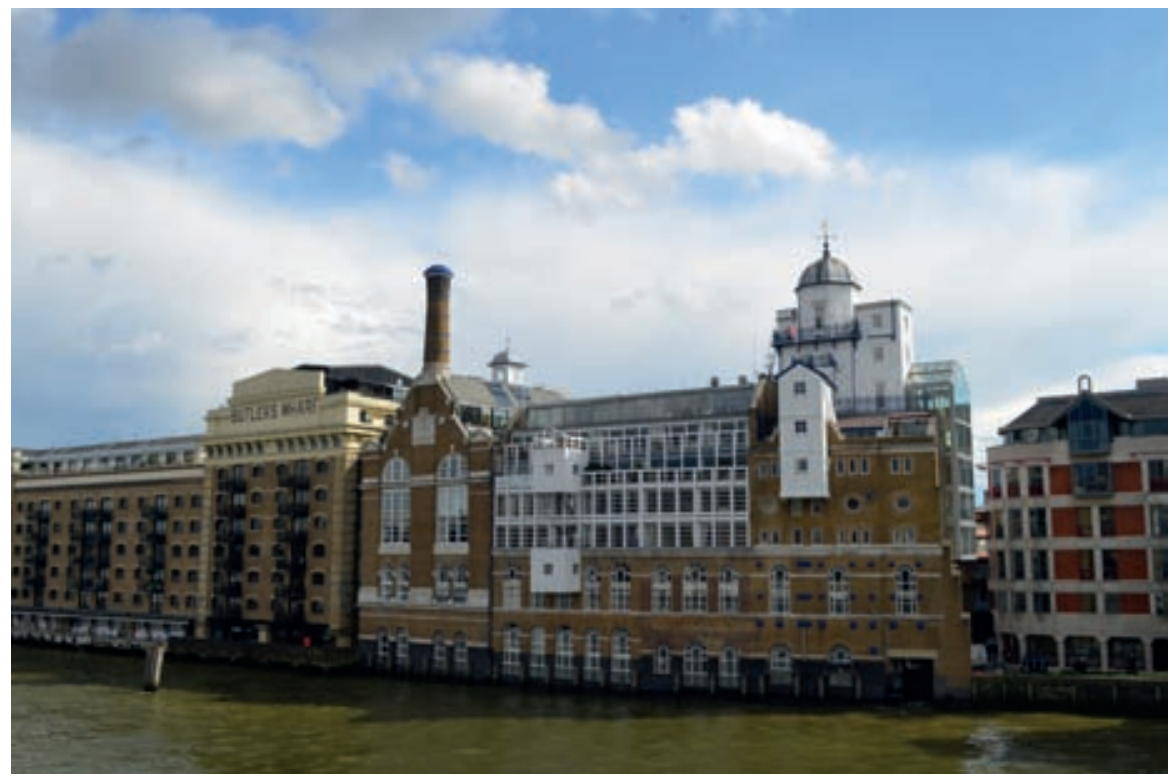

Fot. 4. Anchor Brewhouse - dawny lokalny browar (po prawej) oraz Butlers Wharf dawny magazyn herbaty (po lewej) położone nad samą Tamizą w obrębie Bermondsey Riverside, Londyn, fot. J. Krajewska 2015 


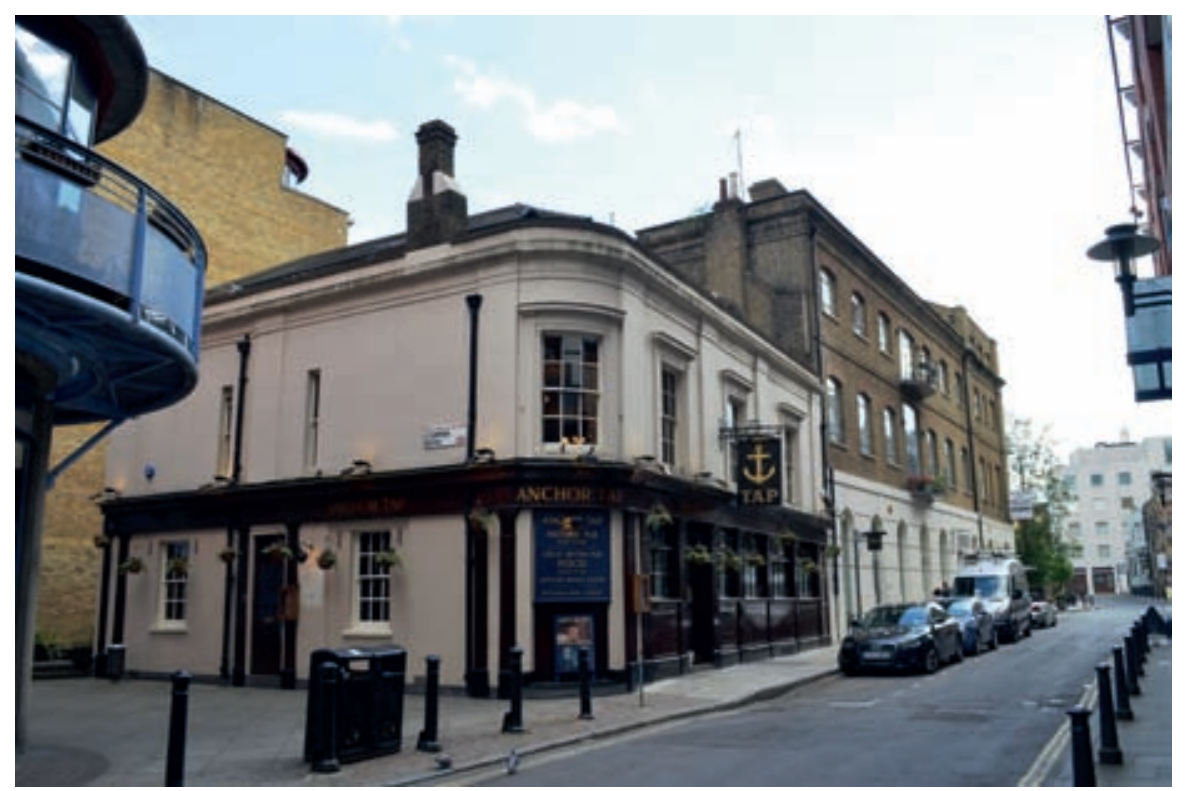

Fot. 5. Anchor Tap - historyczny pub na terenie Bermondsey Riverside, Londyn, fot. J. Krajewska 2015

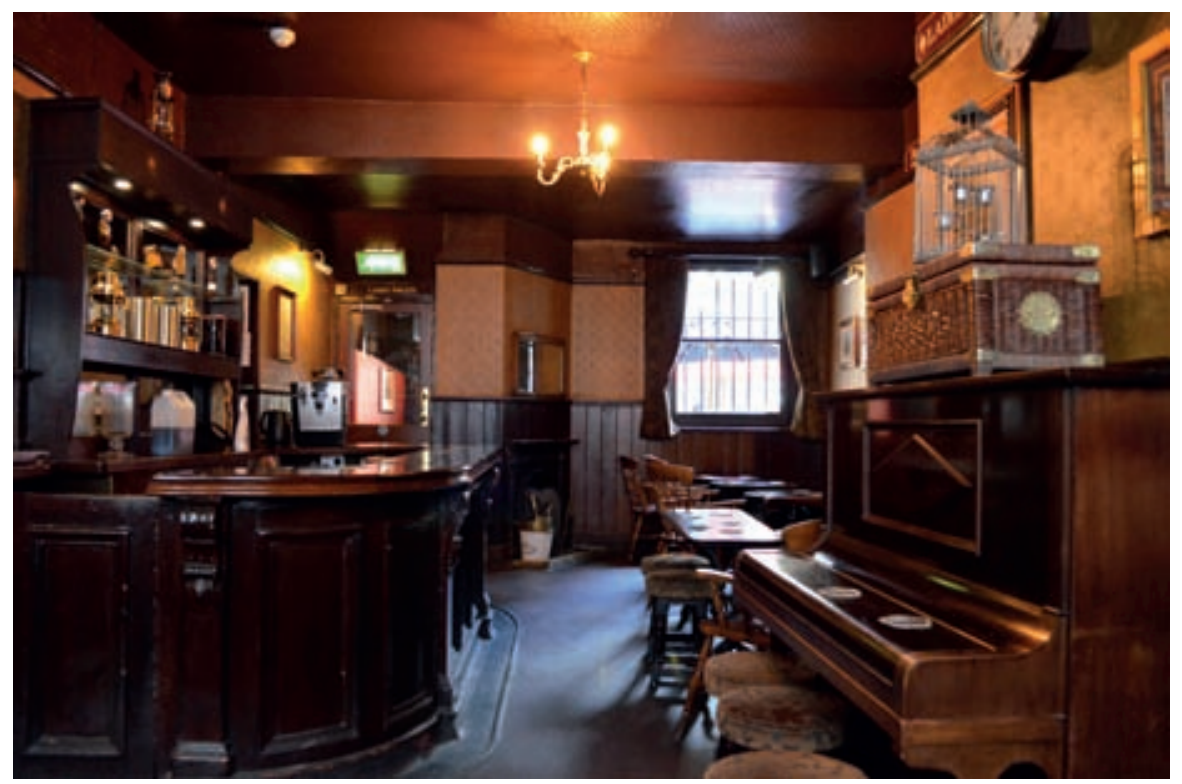

Fot. 6. Jedno z pomieszczeń pubu Anchor Tap, gdzie utrzymano historyczny wystrój wnętrza, Londyn, fot. J. Krajewska 2018 


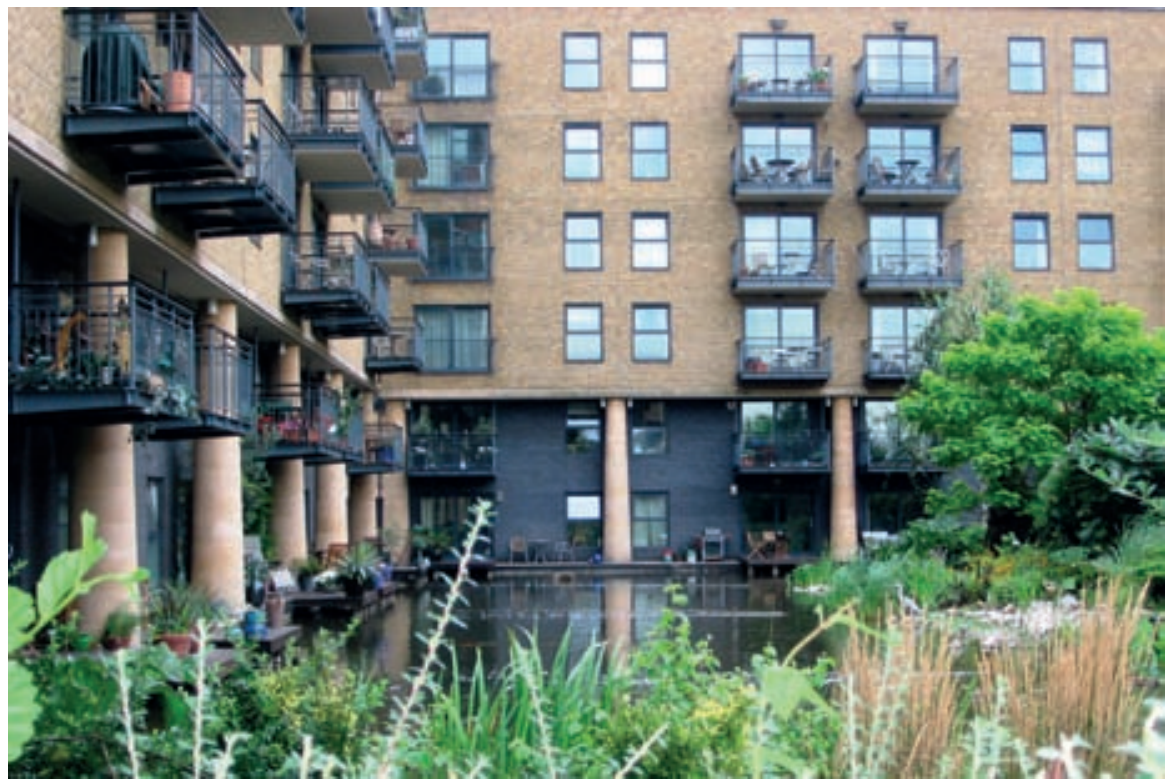

Fot. 7. Zabudowa mieszkaniowa od strony zamykanego dziedzińca z wodą i bujną roślinnością, Bermondsey Wall W, Londyn, fot. J. Krajewska 2010

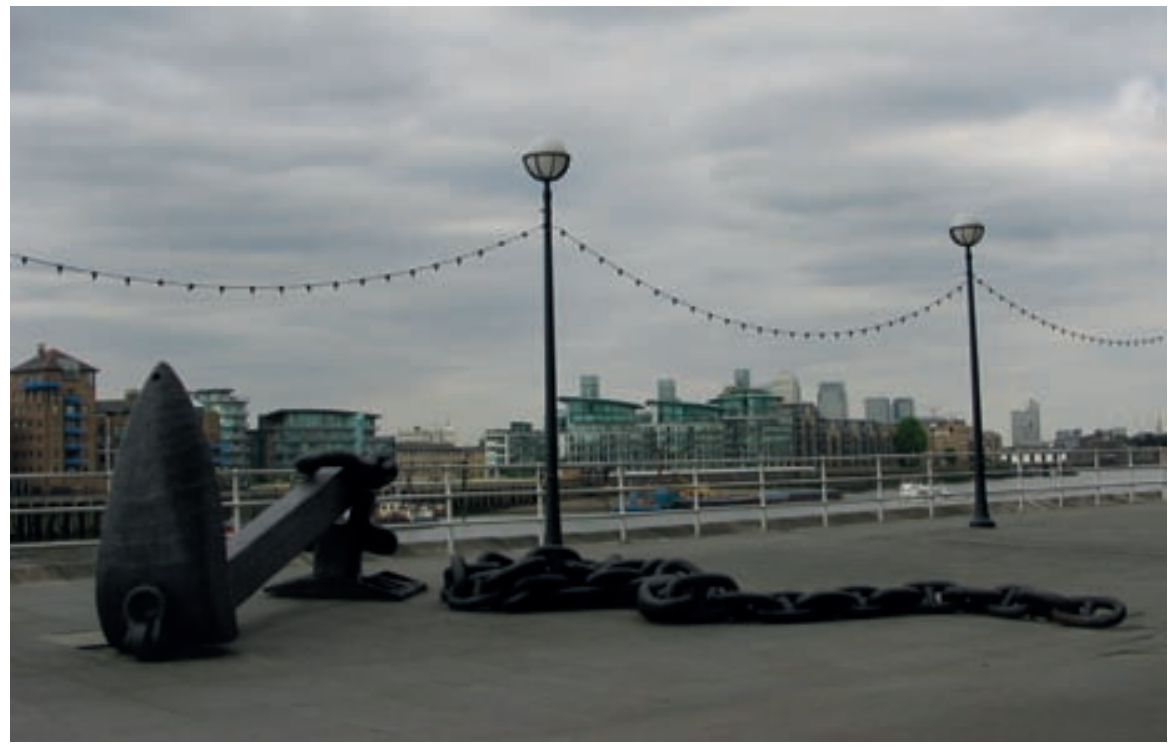

Fot. 8. Rzeźba w formie kotwicy na bulwarze Butler's Wharf, Londyn, fot. J. Krajewska 2008 
historyczną (w dużej części ceglaną) uzupełniają zespoły mieszkalne z 2. poł. XX wieku wpisujące się w zastany kontekst; spotyka się też galeriowce - budynki charakterystyczne dla mieszkań socjalnych.

Od samego początku rewitalizacji Docklands towarzyszyły kontrowersje. Powodem było rynkowe ukierunkowanie przemian, idące w parze ze społeczną wymianą - usunięciem społeczności byłych robotników zamieszkujących te obszary i wprowadzeniem w jej miejsce klasy średniej. $Z$ tego względu byłe tereny portowe Londynu są postrzegane jako dobitny przykład społecznej rewitalizacji tkanki miejskiej ${ }^{71}$. Brian C. Edwards określa „dziedzictwo doków” formą "przynęty dla rozwoju” (ang. development lure), mającej przyciągnąc inwestorów ${ }^{72}$. W wielu przypadkach heritagization - $\mathrm{w}$ rozumieniu instrumentalnego traktowania "dziedzictwa” - okazało się bardzo rentowne, skutkując realizacją wielu biurowców i kompleksów mieszkalnych. Być może właśnie szybkość i chaotyczność, $\mathrm{z}$ jaką podjęto się zagospodarowania tych obszarów w ostatnich dwóch dekadach XX wieku, stanowi odbicie sytuacji, w jakiej tereny portowe rozbudowywano przeszło sto lat wcześniej, błyskawicznie wykorzystując szanse osiągnięcia korzyści, także poprzez spekulacje ${ }^{73}$. Niewątpliwie teren Bermondsey Riverside uległ przy tym gentryfikacji, podobnie jak inne obszary Docklands, choć zjawisko to nie dotknęło całej dzielnicy w równym stopniu. O społecznej wymianie, jaka dokonała się tam w ostatnim trzydziestoleciu ubiegłego wieku, świadczą elitarne zespoły zabudowy mieszkaniowej, zamykane podwórza, a także reprezentacyjny bulwar wzdłuż Butler’s Wharf.

Pozostawienie historycznej substancji architektonicznej (zaadaptowanie obiektów portowych do nowych celów) oraz niektórych urządzeń portowych (np. żurawie) pozwala, w pewnym stopniu, na zmysłowe doświadczanie przeszłości ${ }^{74}$. Poprzez takie działania $\mathrm{w}$ ramach nowych inwestycji rewitalizacja pozwala na „tworzenie przestrzeni historycznej”, o czym pisał Andrzej Szpociński ${ }^{75}$. Służy to zachowaniu tożsamości miej$\mathrm{sca}^{76} \mathrm{w}$ wymiarze materialnym. Dodatkowo na terenie Bermondsey współczesne obiekty infrastruktury i mała architektura, jak pomosty czy rzeźby dosłownie odwzorowujące elementy wyposażenia statków (np. rzeźba w kształcie kotwicy - zob. fot. 8), również mają podkreślać historyczną tożsamość miejsca, wiązać teraźniejszość z przeszłością. Warto zwrócić także uwagę, że wszystkie obiekty, mimo przebudowy i zmiany funkcji, zachowały swoje historyczne nazwy, które są często wyraźnie widoczne - wypisane na

${ }^{71}$ Butler 2007, 8.01.2018.

72 Edwards 1992, s. 10.

${ }^{73}$ Słowa na potwierdzenie tego przypuszczenia można znaleźć w książce Petera Ackroyda, który w podobny sposób pisze o zmianach urbanistycznych na terenach Docklands; zob. Ackroyd 2011, s. 760. Takiego zdania jest też Brian Edwards, gdy pisze: „Spekulacyjne budowanie domów to bardzo stary sposób zarabiania pieniędzy w Londynie”.; Edwards 1992, s. 154; tłum. J.K.

${ }^{74}$ Szpociński 2005, s. 298.

75 Szpociński 2005, s. 299.

${ }^{76}$ Problematykę tożsamości miejsca w kontekście antropologicznym i architektonicznym szczegółowo analizuje Jacek Gądecki; zob. Gądecki 2005. 
elewacjach budynków. Wymienione powyżej elementy przestrzeni można odczytać jako „nośniki pamięci”, stymulujące pamięć o przeszłości ${ }^{77}$. Ich obecność potwierdza zjawisko, na które wskazał Szpociński - wzrost zainteresowania „tak zwanymi «zabytkami drugiej kategorii»”78 oraz ich rolę - „potwierdzanie, że przeszłość realnie istniała”79.

Nadawanie budynkom nowej funkcji, przy zachowaniu historycznego wyglądu zewnętrznego, stało się powszechną tendencją. „Teoria konserwacji jest sztuką znalezienia równowagi", twierdził Wilfried Lipp ${ }^{80}$, i taki kompromis w przypadku rewitalizacji dawnej zabudowy portowej zdaje się być zachowany. Wydaje się jednak, że na analizowanym terenie dokonano zbyt wielu transformacji w kierunku implementacji funkcji mieszkalnej. Większe zróżnicowanie funkcjonalne (np. przeznaczenie przestrzeni na różnego typu działania artystyczne) sprzyjałoby wytworzeniu się lokalnego kolorytu i kształtowaniu się nowej specyfiki miejsca. Ponadto, za Brianem Edwardsem, można zwrócić uwagę na fakt, iż liczne dawne obiekty portowe znalazły się w prywatnych rękach i nie są publicznie dostępne ${ }^{81}$. Komercjalizacja dziedzictwa, poddawana krytyce przez Sharon Macdonald ${ }^{82}$, doprowadziła w przypadku wspomnianych obiektów do ich zawłaszczenia przez prywatny kapitał i przebudowy w kierunku elitarności.

W kontraście do materialnego dziedzictwa Docklands na analizowanym obszarze Bermondsey, dziedzictwo niematerialne, społeczne ${ }^{83}$ - lokalna kultura portowa - nie przetrwało. Może nic w tym dziwnego, gdyż w latach 60. i 70. XX wieku doki pustoszały, a bez specyfiki portowej pracy nie mógł w pełni przetrwać „duch miejsca” ${ }^{84}$. Pamięć o ludziach zamieszkujących niegdyś Docklands oraz o ich kulturze została przez współczesnych „zmagazynowana” w Museum of London Docklands, otwartym w 2003 roku.

\section{Bibliografia}

Ackroyd P. 2011, Londyn. Biografia, Zysk i S-ka Wydawnictwo, Poznań.

Beswick C.-A. 2001, Public-Private Partnerships In Urban Regeneration: The Case of London Docklands, University of Calgary; https://www.ucalgary.ca/ev/designresearch/projects/2001 /Urban_Regeneration/London.pdf, 26.01.2018.

\footnotetext{
77 Szpociński 2014, za: Kula 2002.

78 Takimi jak „fragmenty muru, hale fabryczne, zwykłe budynki, narzędzia itp.”; Szpociński 2005, s. 299.

79 Szpociński 2005, s. 299.

${ }^{80}$ Lipp 2007, s. 189.

${ }^{81}$ Edwards 1992.

${ }^{82}$ Zob. Macdonald 2013.

${ }^{83}$ Dziedzictwo społeczne badał m.in. Jerzy Szacki, zwracając uwagę na fakt, iż warunkiem przetrwania kultury jest nie tylko możliwość jej społecznego dziedziczenia, ale też transformacji, z racji jej żywotności i dostosowywania do współczesności; Szacki 1971, s. 124-143.

84 „Duch miejsca”, genius loci związany jest ze znaczeniem miejsca i obecnością odwołań do czytelnego kodu kulturowego, zob. Rewers 2009.
} 
Butler T. 2007, Re-urbanizing London Docklands: Gentrification, Suburbanization or New Urbanism?, "International Journal of Urban and Regional Research", Vol. 31.4, http://onlinelibrary.wiley.com/doi/10.1111/j.1468-2427.2007.00758.x/full, 8.01.2018.

Conrad J. 1969, Zwierciadto morza: opowieść, Państwowy Instytut Wydawniczy, Warszawa.

Docklands Joint Committee 1976, London docklands: A strategic plan: a draft ... for public consultation, Docklands Development Team.

Drozda Ł. 2017, Uszlachetniając przestrzeń. Jak działa gentryfikacja i jak sie ją mierzy, Instytut Wydawniczy Książka i Prasa, Warszawa.

Edwards B. C. 1992, London Docklands: Urban Design in an Age of Deregulation, Butterworth-Heinemann, Oxford.

Gądecki J. 2005, Architektura i tożsamość: rzecz o antropologii architektury, Wydawnictwo Rolewski, Złotoryja.

Jencks Ch. 1987, Ruch nowoczesny w architekturze, Wydawnictwa Artystyczne i Filmowe, Warszawa.

Kochanowska D. 1998, Przestrzeń publiczna - przestrzeń kulturowa miast portowych w transformacji, Kochanowski M. (red.), Współczesne metamorfozy miast portowych, Wydawnictwo Politechniki Gdańskiej, Gdańsk, s. 45-54.

Kula M. 2002, Nośniki pamięci historycznej, DiG, Warszawa.

Lipp W. 2007, Teoria konserwacji zabytków i jej zmienne koncepcje. Próba rozwiązania zawitości, [w:] Murzyn M., Purchla J. (red.), Dziedzictwo kulturowe w XXI wieku. Szanse i wyzwania, Międzynarodowe Centrum Kultury, Kraków, s. 183-190.

Lorens P. 1998, Instrumenty i mechanizmy przeksztatceń zdegradowanych terenów frontów wodnych miast portowych, [w:] Kochanowski M. (red.), Współczesne metamorfozy miast portowych, Wydawnictwo Politechniki Gdańskiej, Gdańsk, s. 55-84.

Lorens P. 2013, Obszary poportowe - problemy rewitalizacji, Fundacja Instytut Studiów Regionalnych, Szczecin.

Macdonald S. 2013, Memorylands. Heritage and Identity in Europe Today, Routledge, London.

Muir R. $2^{\text {nd }}$ (ed.) 2012, Pubs and places: The social value of community pubs, Institute for Public Policy Research.

Powell K. 2004, City Reborn: Architecture and Regeneration in London, from Bankside to Dulwich, Merrell, London.

Rewers E. 2005, Post-polis. Wstęp do flozofii ponowoczesnego miasta, Towarzystwo Autorów i Wydawców Prac Naukowych Universitas, Kraków.

Rewers E. 2009, Od miejskiego genius loci do miejskich oligopticonów, [w:] Gutowski B. (red.), Fenomen genius loci. Tożsamość miejsca w kontekście historycznym i współczesnym, Muzeum Pałac w Wilanowie - Uniwersytet Kardynała Stefana Wyszyńskiego, Warszawa, s. $15-26$

Szacki J. 1971, Tradycja, Państwowe Wydawnictwo Naukowe, Warszawa.

Szpociński A. 2005, Autentyczność przesztości jako problem kultury wspótczesnej, [w:] Szpociński A. (red), Wobec przeszłości. Pamięć przeszłości jako element kultury współczesnej, Instytut im. Adama Mickiewicza, Warszawa, s. 292-301. 
Szpociński A. 2014, Nośniki pamięci, miejsca pamięci, "Sensus Historiae", Vol. XVII (2014/4) s. 17-26,http://sensushistoriae.epigram.eu/index.php/czasopismo/article/viewFile/230/233, 28.06.2019.

Załuski D. 1998, Od portofobii do portofilii. Wspótczesne kierunki przeksztatceń dzielnic portowo-przemystowych, [w:] Kochanowski M. (red.), Współczesne metamorfozy miast portowych, Wydawnictwo Politechniki Gdańskiej, Gdańsk, s. 11-32.

Żyłko B. 2011, Kultura i znaki. Semiotyka stosowana w szkole tartusko-moskierwskiej, Wydawnictwo Uniwersytetu Gdańskiego, Gdańsk.

\section{Źródła internetowe}

Anchor Brewhouse: https:/www.londonremembers.com/memorials/anchor-brewhouse, 7.02.2018.

British Listed Buildings: https://www.britishlistedbuildings.co.uk, 6.02.2018.

CAMRA: https://whatpub.com/pubs/SEL/10483/anchor-tap-london, 29.06.2019.

Conran + Partners: http://conranandpartners.com/project/butlers-wharf-limited-butlers-wharf/, 26.01.2018.

Courage\&Co.: http://takecourage.info/, 30.06.2019.

CZWG: www.czwg.com, 20.01.2018.

English Heritage: http://www.english-heritage.org.uk, 6.02.2018.

European Heritage Awards: http://www.europeanheritageawards.eu, dostęp: 7.02.2018.

LDDC: http://www.lddc history.org.uk/timeline/index.html, dostęp: 6.02.2018.

Mapowanie Londynu wg powieści Karola Dickensa: https://londonist.com/2016/09/the-london -of-charles-dickens-mapped, 24.01.2018.

Museum of London Docklands: https://www.museumoflondon.org.uk//museum-london-doc klands, 8.01.2018.

Pollard Thomas Edwards: http://pollardthomasedwards.co.uk, 6.02.2018.

Prezentacja konferencyjna Stewarta Innesa: http://www.lddc-history.org.uk/other/lddcpresent 09conf.pdf, 24.01.2018.

Pub Heritage: https://pubheritage.camra.org.uk/pubs/2232, 30.06.2019.

The Cardamon Building: https://www.britishlistedbuildings.co.uk/101385908-the-cardamon -building-riverside-ward\#.WnmETVXibIU, 6.02.2018.

The Dean Swift: http://thedeanswift.com/about-us/, 29.06.2019.

Urban Spaces: http://www.urbanspaces.co.uk/development-guides/butlers-wharf, 25.01.2018. 
